\title{
MODELS OF JUSTICE IN AMERICAN FOLKLORE
}

\section{A. A. Osmushina}

Federal State Budgetary Educational Institution of Higher Education «National Research Ogarev Mordovia State University», Saransk, Russia

e-mail: 98761985@mail.ru

Abstract. The relevance of the study is that the models of justice in American folklore have never been considered. This work aims at revealing the peculiarities and content of the concept of justice in American folklore and since the American folklore has been made up of the folklore of various ethno-social groups that make up American society, this study aims at revealing the semantic differences in the models of justice of the different races, ethnicities, and cultures that comprise the USA. The research was carried out within the framework of philosophical comparativism, while the approach was analytical-deductive and comparative-historical. The methodological basis of the study was the principle of identifying differences in similarities. I used the method of critical selection of sources as well as the method of content analysis of tales, myths and legends of the largest American ethnic and racial groups, namely Native Americans, African Americans, and European immigrants. The results of the study demonstrate differences in the content of the models of justice of different American ethnic and social groups. The analysis allowed me to create a general formula for the American justice model and the functions of justice in society. This work provides a better understanding of the thinking and worldview of American social groups and American society as a whole. The scientific novelty of the study is the identification of the contents of models of justice in a multi-ethnic American society. The practical significance of the results is that they can and should be applied in the dialogue of cultures. In further research, it is necessary to continue studying the models of justice of different ethnic and social groups and to determine the optimal interethnic models of interaction based on justice.

Key words: American justice model, ethnic-social groups, demographic justice, economic justice, political justice, professional justice, cultural justice, religious justice, justice functions.

Cite as: Osmushina, A. A. (2021) [Models of justice in American folklore]. Intellekt. Innovatsii. Investitsii [Intellect. Innovations. Investments]. Vol. 5, pp. 104-113. DOI: 10.25198/2077-7175-2021-5-104.

\section{МОДЕЛИ СПРАВЕДЛИВОСТИ В ФОЛЬКЛОРЕ США}

\section{А. А. Осьмушина}

ФГБОУ ВО «Национальный исследовательский Мордовский государственный университет им. Н. П. Огарёва», Саранск, Россия

e-mail:98761985@mail.ru

Аннотация. Актуальность исследования заключается в том, что модели справедливости в фольклоре США никогда никем не рассматривались. Цель настоящей работь - выявить особенности и содержание концепта справедливости в фольклоре США, а, поскольку фольклор США состоит из фольклора различных этносоџиальных групп, составляющих американское общество, задачами исследования становится выявление смысловых различий в моделях справедливости разных этно-расовых и культурных группах США в процессе формирования и развития Американского общества и фольклора. Исследование выполнено в рамках философского компаративизма, подход - аналитико-дедуктивньии, сравнительноисторический. Методологическую базу исследования представляет принции выявления различий в сходствах. Применяются метод критического отбора источников, а также метод контент-анализа сказок, мифов и легенд крупнейших этнорасовых групп США, а именно коренных американцев, афроамериканцев, европейских переселенцев и их потомков. Результаты работы демонстрируют различия в содержании моделей справедливости разных этносочиальных групп США. Проведенный анализ позволил нам сформулировать общую формулу американской модели справедливости и функции справедливости в обществе. Настоящая работа позволяет лучше понять особенности мышления и миропонимания как в рамках общественных групп, так и в обществе США в цчелом. Научная новизна исследования состоит в выявлении содержания моделей справедливости в мультиэтническом американском обществе. Практическая значимость полученных результатов состоит в том, что они могут и должны получать применение в диалоге культур. В дальнейших исследованиях следует продолжить изучение моделей справедливости разных этносоциальных групп и определить оптимальные межэтнические модели взаимодействия на основании справедливости. 
Ключевые слова: американская модель справедливости, этносоциальные группь, демографическая справедливость, экономическая справедливость, политическая справедливость, профессиональная справедливость, религиозная справедливость, культурная справедливость, функичи справедливости.

Для цитирования: Osmushina, A. A. (2021) [Models of justice in American folklore]. Intellekt. Innovatsii. Investitsii [Intellect. Innovations. Investments]. Vol. 5, pp. 104-113. DOI: 10.25198/2077-7175-2021-5-104.

\section{Introduction}

Many categories of ethnic thinking, psychology, and philosophy are reflected in folklore. Justice is one of the most important and the most frequently encountered concepts $[7 ; 8]$. However, justice models in folklore have never been investigated.

I base my conception of justice on the theory of Andrei Gagaev that defines justice as a form of equality, or the occupation of the designated position in the natural hierarchy, the evolutionary possibility of the development of races and ethnic groups, the validity of the space-time concerning generations and the natural diversity [2]. I interpret justice as a conception including personal and ethnic development $[5 ; 6]$. Justice comprises self-organization and self-realization [25], includes productive work and participation in the affairs of the state [10]. Justice demands the expanded reproduction of ethnicities [17] and ethnic identity [14; 21]. Justice is the form of truth [17]. Justice comprises the teleology of perfection and the antinomies of nonviolence in action [17].

The model of justice is the content of the concept of justice within a certain approach/social context/folklore/ethnoculture. Revealing the content of justice in folk tales, I rely on such concepts as truth [17], equality or taking a position in the natural hierarchy, equal rights, freedom and responsibility, the possibility of the development of races and ethnic groups in evolution, a careful attitude to generations and natural diversity, and resistance to oppression [17].

My work aims at revealing the peculiarities and the content of the concept of justice in American folklore. However, American folklore is not a homogeneous entity but has been made up of the folklores of the ethnicsocial groups that have made up American society [16]. Therefore, I aim at revealing the semantic differences in the models of justice of different races, ethnicities, and cultures that comprise the United States in the process of the formation of American folklore during the development of the American society.

Thus, the objective of this study is to conduct a content analysis of the folklore of the largest ethnic groups that make up a significant part of American society, namely Native Americans, African Americans, first settlers, multi-ethnic European migrants, and the descendants of each, and finally, modern American folklore.

The folklore of the above-mentioned ethnic and racial groups is chosen as the material for the study since folklore preserves and reflects the worldview, thinking, norms and values, concepts of truth and falsehood, the models of good and evil, and cultural universals of the ethnic group. The object of our study is more than 1000 folk tales, myths, and legends $[11-13 ; 15 ; 18 ; 20 ; 22$; $24 ; 26 ; 28-31 ; 32 ; 34 ; 35]$ chosen by a random selection. I applied the critical source method, being careful to pick out folklore avoiding the so-called fakelore [15]. The subject of the study is the models of justice in the representation of the ethnic and racial groups that make up American society.

\section{Methods}

The research methodology was based on the principle of revealing differences in similarities, which allowed me to identify differences in similar folk tales, myths, and legends that demonstrate the ethnic group's thinking [27] and peculiarities of worldview [19; 33]. To achieve the goal, I applied a deixis approach within the framework of analytical philosophy as well as general scientific methods of comparison, classification, analysis, and synthesis. The research was carried out within the framework of philosophical comparativism, using an analytical-deductive and comparative-historical approach.

Considering the object of research from different positions and different approaches, I revealed its various aspects. In my article, I investigated models of justice in all social contexts, namely demographic, economic, political, migration, educational, professional, cultural, and religious. Then I investigate various models of natural justice, specifically formal [7], selective [7], procedural [7], pejorative [7], desiderative [7], restorative [4], adstrate [4], general [4], evolutionary/ psychogenetic [4], ecological [9], historical [7], pedagogic [8], and the model of justice in the system of life activity [7].

\section{Results \\ Native American \\ The model of justice in the demographic context of the tale}

Following natural life cycles is very important. While family life, safety for children, and care for women and the sick are regarded as normal and just («The Trickster Becomes a Dish», "The Deceived Blind Man» [32]), violating natural life laws, i. e. adultery, incest, deserting one's children, is considered unjust and leads to the death of the tribe and the ethnos, resulting in people ceasing to exist as a species ( Lecherous Father and his Daughter», "The Emergence», "The Girl who Married a Dog», "Loon-woman» [12], «The Deserted Children», «Sun Sister and Moon Brother», "Mudhikiwis» [32]). Demographic 
justice implies that children are the most precious beings. Women are regarded as free to choose a husband (healthy appearance and behavior are important in the choice as well as hope for a decent life). Equally, a woman is considered free to leave her husband in cases of mistreatment or abuse ( $«$ Sedna», «Splinterfoot-girl» [32]). The elderly are regarded as a source of wisdom ("Mudhikiwis», «Dug-from-ground» [32], "The Origin of the Pleiades» [12]). Children that ignore their advice get exposed to dangers. Thus, in the tale «Afterbirth Boy and Lodge Boy» [12] the children of the leaders who entered into cohabitation without their parents' permission are exiled; the wife who violated the husband's prohibition is killed. Upon ignoring the prohibitions of their father, children are exposed to deadly danger and overcome it thanks to their ingenuity. Justice includes hunting only for necessary food and preserving the species, since the unity of all things is valued ("The Beginning of Newness», «The Creation» [32]). The model of justice suggests that men and women live together and share their responsibilities according to their gender characteristics («The Beginning of Newness», «Mudhikiwis» [32]). Care for the children and respect for parents is vividly demonstrated in the tale «The Jealous Uncle» [32]: the parents are trying their best to save their son from the jealous uncle and later the grown-up son punishes the uncle for the cruel treatment of his parents.

\section{The model of justice in the economic context of the tale}

Common ownership is considered fair and normal, unlike private land ownership. The good of the whole is more important than the good of the invididual. Resources must belong to the community. Thus, in the tale "The Impounded Water» [32] Anglabem took all the water and was killed so that everyone could have water. In the tale "The Release of the Wild Animals» [32] an old woman and her young cousin penned all buffalo, so Coyote released the animals for everybody.

The model of justice in the political context of the tale includes the right to resolve political issues both in a peaceful and revolutionary way, and the right of everyone to demonstrate leadership qualities and take a role of leadership. One widespread motif is the young man passing tests and becoming a chief, for example, «Bloodcloth» [12], "The Sun Tests his Son-inlaw» [32]. A young man kills the cruel chief and takes his place in «The jealous uncle» [32].

The model of justice in the migration context of the tale requires peaceful coexistence of ethnicities and races. The unity of groups and importance of abiding by the law is a normal way of living while war is evaluated as a wasteful, unhappy, and unjust disaster ( A Tewa Emergence Creation Myth» [24]).

The model of justice in the professional context of the tale demands a hard-working attitude, while those who are lazy perish («The Enchanted Horse» (Malecite), "Cinderella (Zuni)», "The Ant and the Grasshopper (Shuswap)» [32]).

The model of justice in the educational context of the tale demonstrates that an individual should study and develop, watch, learn and refine one's skills ("The bag of winds» [32], «The Iroquois Hiawatha», "The Ojiba Corn Hero» [24]).

The model of justice in the cultural context of the tale is unity in tradition. Freedom to pass on traditions, following the Primordial tradition of the ancestors is evaluated as fair and normal ( $"$ The Story of Sweet Medicine» [12], "A Brule Sioux Myth of the Coming of the White Man», "A Sioux Myth of White Buffalo Woman» [24]).

The models of justice in the religious context of the tale requires following traditional religious truths. Justice includes freedom to perform religious rites, communicate with gods, and do their will the way traditions demand it ( A Brule Sioux Myth of the Coming of the White Man» [24], «The Creation» [32]).

\section{First settlers}

The model of justice in the demographic context of the tale is based on the principle of supporting the weak who are in trouble. Chivalry is a highly valued virtue. Help to the poor, widows, and children is considered just and, on the contrary, adultery is viewed negatively ("The Colonel Swallows a Thunderbolt», «Billy the Kid», "Jesse James», "Sam Bass», etc. [11]).

\section{The model of justice in the economic context of the tale}

First settlers claimed that hardships bring out the best in men. The role of industry has resulted in the weakening of man: «they had iron men and wooden ships; now they got iron ships and wooden men» («Stormalong» [24]). A pioneer is an individualist but mercantile honesty is seen as virtuous as a guarantee of political honesty. Nonetheless, hard life conditions form a condescending attitude to small-scale fraud, especially if it allows the hero to amuse his friends ( $"$ Billy the Kid», "Jesse James», "Davy Crockett» [24], «Sam Bass» [11]).

\section{The model of justice in the political context of the tale}

While a hero of Native Americans' tales can show his skills, powers, and virtues, and become a leader, and a European folk tale hero can raise his or her social status by becoming a king or marrying a royal descendant, a pioneer can attract voters, win elections, and become a governor, senator, or congressman to bring some good to the state. Social order is more important than legal justice, so common sense is more important than a fair trial if a fair trial can cause public disorder («Judge Roy Bean» [24]). 
The model of justice in the migration context of the tale

Despite the strained relations with representatives of other ethnic groups (Native Americans, Asian migrants) a just Tall Tale hero avoids killing without a reason. Constant wars with other races are caused by competition for the possession of land and resources («Wild Bill Hickok» [11]).

\section{The model of justice in the professional context of the tale}

People should not avoid hard work because difficult times bring out the best in people. Excessive vitality, patience, and cunning are highly valued ( John Henry» [24]). Creativity and creative work are also appreciated («Paul Bunyan» [24]).

\section{The model of justice in the educational context of the tale}

A person should pay attention to the world around them, especially nature, in order to use every part of it for their survival («Johnny Appleseed» [24]). Academic education is also valued; people should study hard and read good books ( Abraham Lincoln - Honest Abe» [24]). Unequal access to education is unjust.

The model of justice in the religious context of the tale is based on people's equal rights to follow their religion («Roy Bean, Law West of the Pecos» [11]).

\section{The model of justice in the cultural context of the tale}

Survival in the wild new world, conquering the new world, competitiveness for the possession of land alongside constructing a new society equally fair for everyone make up the content of the cultural model of justice («Crockett Electioneering», etc. [11]).

\section{XVII-XIX century European immigrants The model of justice in the demographic context of the tale}

Children are considered the most valuable and the most vulnerable social group, and justice demands the necessity to protect them and care for them. Elderly people are regarded as a source of wisdom, while violating their advice threatens the death of children and consequently humanity as a whole («The Gunny Wolf», «Little Eight John», etc. [11]).

\section{The model of justice in the economic context of the tale}

We see that private ownership of land begins to define the relations within the society («Quevedo Holds his Ground» [26]).

\section{The model of justice in the political context of the tale}

The perception of government and power differs from what we see in European folk tales of the same period. The power of the king ceases to be absolute (folk tales "The Girl with the Basil», «Juan Bobo and the Riddles of the Princess» [26]). The tale «The Little Son of the Government» [26] describes the government as a one-legged man, tall and terrible, but crippled and distorted. This image has parallels in folk tales of other cultures, both Eastern and Western. The distorted creature, half-man, that took away from the man the power over his own life, appears as Patasola or Tunda in Colombian legends, Paelsmurt in Udmurt tales [3], Gagdanchu-Marga in Nanai folklore, Arkhatov in Chuvash tales, Yag-morta and Kort-Aika in Komi folklore, Kuigorozh in Moksha folk tales, and Liderts in Hungarian folk tales and legends.

The model of justice in the migration context of the tale denies any war («The Virgin of Guadalupe» [24]).

The model of justice in the educational context of the tale implies accessibility of education. The belief of education for everyone regardless of gender appears in the tale «Seven Robbers» [26].

The model of justice in the professional context of the tale includes the free choosing of one's profession («Seven Robbers» [18]).

\section{The model of justice in the religious context of the tale}

Following the truth of Christ defines justice. Such values as Christian forgiveness, kindness, care for the weak, the old and children, and help for the poor are confirmed in the folk tales "Cat's Skin», "The Flower of Olivar», "Children and the Giantess», "The Girl without Arms, Breasts, and Eyes» [26]). Even Cinderella goes not to the ball, but to the mass ("Golden Star» [26]).

The model of justice in the cultural context of the tale is based on the construction, socialization, and mobility of society («The Basil Maiden», "The Little Boy of the Government», "John the Bear» [26]).

\section{African American}

The model justice in the demographic context of the tale aims at the ethnic-social group preservation. Children's protection and upbringing are the cornerstones of the concept. Mother usually acts as the source of wisdom ("Little eight John», "Wiley and the Hairy Man» [11]). The tale "Little Eight John» [11] shows the attitude of the ethnic group to demographic justice. A disobedient child brings misfortune, disease, and poverty to his family, and finally ceases to exist. For example, "The Dying Bullfrog» and «The Eagle and his Children» say, "A heap of people are willing to notice a pretty young widow, but they don't want to bother themselves with another man's children» [13, p. 487], and «Mind your children well when they're little; as soon as they're big enough to work, make them work» [13, p. 488-489]. 
The model of justice in the economic context of the tale is defined by the historical situation. Poverty, hunger, limited opportunities to earn money, lack of access to property and resources are the components of injustice. Impossible living conditions justify theft and dishonesty ("John Steals a Pig and a Sheep», "Baby in the Crib», "The Mojo», "John's Watch», and "The Ducks Get the Cotton» [13]).

Only an outstanding act of heroism and deep gratitude of the master can give a slave economic and political freedom, though not a decent social position. An example is the tale «John Saves Old Master's Children» [13].

If we compare the tales of different ethnic groups that share similar motifs it is the differences that demonstrate the ethnic thinking mode.

The African-American tale "The Champion» [13] has an analog in Chile (Laval). The plot outline is the following: a weaker person enters into a battle assignment with a real wrestling champion. However, in the Chilean folk tale, the hero needs money to return home, and in the African-American one, he has no choice, because his master and the master of the champion have a bet. The hero understands that he will not be able to win in a fair fight, so he comes up with a trick: he ties himself to the trees that he dug up in advance, and falls these trees in front of the champion. Thus, the champion refuses to fight. If in the Chilean folk tale the cunning man gets the reward, in the African-American folk tale the hero gets nothing; his master takes the prize.

The inequality in private property and the disenfranchisement of the worker are unjust. So, a folk tale with the theme «Tops and roots» can be found in different ethnic groups' folklore. In the German folk tale "Der Bauer und der Teufel» [19] the farmer owns the field, and the devil owns the treasure buried in this field which causes a legal conflict. The devil offers the man his treasure in exchange for half of (not all!) his harvest in the next two years. We see a bargain of equal subjects of law, and justice in law legislation, which even the Devil obeys. In the Chilean folk tale «El Campesino $y$ el Diablo» [23], the devil owns the land, and the man owns the seeds. The devil cannot work and enjoy the fruits of his labor, but he seduces the man with private ownership of the land in exchange for all his crops for the next three years. In the Russian folk tale «The Peasant, the Bear and the Fox» [1] we see the triumph of arbitrary power over the law, and the absence of law. The bear threatens the man with death without any reason, and the man humbly and obsequiously offers him half of his crop, receiving from this transaction only one prize, namely, his own life. In the American folk tale «John Sharecrops for Old Boss» [13], the land owner is looking for a man who will cultivate his field for half of the crop. John has to persuade the master, convince him that he can work his land well, that he is a trustworthy worker. The master expresses a disdain- ful and humiliating attitude towards John's people. It is the owner of the land who offers the terms of the deal, John can only accept them or not. These conditions are unfair, but John comes up with a way to get the fruits of his labor, taking advantage of the greed and shortsightedness of the owner.

The model of justice in the political context of the tale shows the life of an African American during the epoch of slavery as being Hell on Earth. The absence of personal and economic freedom makes a person sell his soul to get a craft and freedom (tales «Sixteen and the Devil», «Jack-O-My Lantern: a Maryland Version», «Balaam Foster's Fiddle» [11]. Inequality is unjust. The tale «The Beginning of Things» [13] describes a common origin of all nations, the primordial equality which was perverted and violated by the cunning of those who became white.

The model of justice in the migration context of the tale reflects social ethnic stratification. Difficult living conditions form the collectivity within the ethnic group and the necessity to stick to one's kin. Identity and identification are demonstrated in the folk tale "John and the Blacksnake» [13]. The snake chose John of all the people because they were both black and spoke to him, but he told his master about the miracle. The fact that John gave her secret away to a white man hurt the blacksnake's feelings. Dishonesty, theft, laziness, and murder are prohibited within the ethnic group: «...no matter how sharp you are, you got to keep on the good side of people, else your smart ways goin' to get you in difficulty. There's a lot to bein' sharp, and maybe you can use it against one critter at a time and come off good, but when it comes to bein' sharp against the whole community at once, it doesn't pay off» $[13$, p. 497].

The model of justice in the professional context of the tale shows the ethnic attitude to the importance of personal development and the limited chances to get a profession. A profession, a craft is assessed as an opportunity to get some freedom. The freedom to engage in creative work is considered just. Meanwhile, work for a master is seen as unjust, so a lazy worker frequently gets away with it («Balaam Foster's Fiddle» [11], "Old Boss, John, and the Mule» [13]).

\section{The model of justice in the educational context of the tale}

Poverty and lack of freedom force parents to deprive their children of the opportunity for education so that they can help the family with work ( Education for a carpenter's son» [18]. This is viewed as unjust and abnormal. Teachers that lack morals and wit are denounced [18, p. 192].

The model of justice in the cultural context of the tale can be expressed in the theme of the tale «Balaam Foster's Fiddle» [11], specifically selling one's soul to gain one's freedom. 
The model of justice in the religious context of the tale is Christianity as equality ( The Creation James Weldon Jobson» [24], "Origin of the Races» [13]).

\section{Modern American Folklore}

The model of justice in the demographic context of the tale is similar to that of the ancestors. Children and teenagers are the ones who need protection. Such virtues as the observance of social norms, obedience to parents, care for children, and conscientious performance of duties are formed. Disobedient and reckless children perish («Hook-arm», «Don't Look Back», "Pond of Snakes», "Call from the downstairs phone» [34], «Island of Fear» [30]).

The model of justice in the economic context of the tale is based on the conception of private property, freedom, and inequality. Theft is prohibited. Greed leads to the violation of justice («The devil and Tom Walker», "The pirate», "The accursed house» [30]).

The model of justice in the political context of the tale A person who is included in social life has freedom for legal actions but collectivity, euthyumia, and eusociality are not inherent in the justice model («A Night of Terrors» [31], «Hold him, Tabb!» [30]).

The model of justice in the educational context of the tale includes freedom to get an education but economically unequal opportunities to do this are considered unjust in the tales «Ignorance is bliss» [22] and «Knock... knock... knock»: «I'm not wasting my hardearned college money on a giant bunny outfit,» he said» [30, p. 148]. Education becomes a social status marker and is frequently mentioned matter-of-factly: «Finally he gave up and went downtown to the library, where he was researching a school paper about the impact of the nearby dam and lake on the environment. As he looked through the microfilms of ten-year-old newspapers, he saw something that made his blood run cold» (tale «The lady from the lake» $[34$, p. 55]). Education is regarded as a chance to escape poverty as in the tale «What goes around comes around» [22].

A similar gap between the intention and reality is noted in the model of justice in the migration context of the tale. War is unjust, destructive, and devastating; moreover, the image of official propaganda does not correspond to reality in the tale «The Secret Message» [22]. War contradicts common sense and humanity in the tale «Civilization advances funeral by funeral» [22] where British Lord Protector Oliver Cromwell, being a fierce Protestant at a time when Protestants were at war with Roman Catholics, refused the Indians' lifesaving medicine because it was defended by Catholic missionaries and, as a result, Cromwell died of malaria. The long-term consequences of war attract public attention. War is considered unjust as chaos, destruction, and horror, all embodied in reality, leave a deep mark and influence the further functioning of societies:
«By and large, the public has become inured to the vagrant who bums change on the street corner, or holds up a «help me» sign at a freeway exit ramp. In reality, an alarming number of these men and women are Vietnam war veterans, homeless, or mentally ill people whom society has come to ignore. They are not criminals, even if local lawmakers sometimes try to pass laws that criminalize what they do» [31, p. 57], «It is 1919 and four years of world war have forever changed civilization. Soldiers return to their homes hardened by the horrors of battle» [31, p. 83].

The model of justice in the religious context of the tale implies that equality and freedom of choice have consequences ("Sister death and the healer», «The Thing in the Woods» [30]).

The model of justice in the cultural context of the tale is the difficult surviving and struggle for a better position in the society where the declared and actual requests, rights, laws, freedom, and equality do not coincide ("Old Wives' Tales», "The Death Penalty is a Deterrent to Murder», «Believe It or Not!» [31]).

I have considered models of justice in social contexts; now I turn to justice models of justice in analysis.

\section{Models of justice in deixis analysis}

The formal model of justice reflects the norms of behavior. It is interrelated with the pedagogic and the selective models of justice.

The selective model of justice demonstrates the criteria for the selection of an individual deserving of remuneration or ascension in social status. Every ethnic group has several tales where the hero goes through tests: in the Native Americans' folklore, the ability to keep one's word in difficult and unpleasant circumstances, endurance, patience, and bravery are rewarded. In the Tall tales, sociability, ability to maintain a conversation with different social groups in the appropriate modes, physical strength, agility, survival skills, and excessive vitality are rewarded. In the tales of European migrants, the hero goes through tests for kindness, mercy, politeness, and diligence. These trials and completing tasks contain the procedural models of justice. The pejorative model of justice consists of punishment of a crime, a condemnation of deviant behavior while the norms of behavior represent a formalized interpersonal justice. Prohibition of incest, theft ( «The Visit to Chief Echo» [32]), greed («The Devil and Tom Walker» [11]), laziness, nonchalance («Buh Turkey Buzzud and de Rain» [11]), impatience («The Man who Acted as the Sun» [32]), disobedience and inattentiveness («Manabozho's Birth» [32]), murder, looting ( «iley and the Hairy Man» [32]), child abandonment, unreasonable killing (tall tale), child mistreatment, rudeness, and disregard of the elderly (the Tradition, the wisdom, the common sense). Violating the rules of socially approved behavior forms the deviant behavior in different tales. Desiderative justice includes equal- 
ity, the law as a form of truth, human development, creative work, excessive energy, family, and children. Native American and African American tales contain restorative justice, i.e. equality in property and land rights. The model of justice in the system of life activity is the identity and identification into the ethnos and the reproduction model of the ethnic group. The adstrate model of justice is the preservation of life in its various forms [13].

The general model of justice is the view that the good of the group is above the good of the individual. Oneida sacrificed herself to save her people [24]. South and North had to separate since their life together harmed people [32]. The chief banished his only beloved son when he threatened to starve the tribe [32]. The tree that gave food to everyone is more important than one woman's health [32]. Johnny Appleseed proclaimed being simple and useful, avoiding the absolute sin of inflicting pain or death upon any creature [24].

The evolutionary/psychogenetic model of justice [4] including ecological justice [9] comprises the preservation of the natural life cycle and natural evolutionary norm of the human, preservation, and compatibility of flora and fauna forms, and mankind. The unity and interrelatedness of all living beings (nature and mankind), and gradual development and harmony of everything in the world is declared in the folk tales of Zuni, Cherokee, Hawaii, Sioux [24; 12], uncle Remus’s «Origin of the Races» [13], and "Johnny Appleseed» [11]. A respectful and careful attitude to nature and prey is demanded in the tale "The Youth who Joined the Deer» [32] and «Yellowtop-to-head Woman» [11]. Contrarily, in the tale "The Story of Sweet Medicine» [11] the arbitrariness of power, and the human whims to have everything he wants lead to the disappearance of animals and starvation, while the desire to resemble a white man destroys the Native Americans who could otherwise live forever in their tradition. The norm is the natural course of things, the joint life of a man and a woman in caring for each other and working, the birth of many children, and, in the care of nature, reserving it and improving the landscape for the good of all («The Man who Married a Branch» [11]).

The historical model of justice includes justice or injustice in history, ethnic genesis form, and preservation of the traditional reproduction model. Thus, in the folk tale of the Sioux [24], we see the tragedy of the tribe, i.e. the loss of identity, religion, food, and life: «He is going to give you false names. He will tame you like taming dogs, and he will make you like yourself. He will lie to you... You must send your people to guard the buffalo, for the white man will try to take them all. He will bring gambling dice, and sickness, and hate. He will insist that you forget Wakan Tanka and believe in his different Great Spirit... If you believe in this new Great Spirit, you will lose your world» [24, p. 25-26].
The pedagogic model of justice is a set of social behavior patterns and corresponding rewards and punishments that model norms and values. Wit and bravery win over evil («The Theft of Fire» [32]), patience and ingenuity save the ethnic group («The Bag of Winds» [32]), the good and confident can overcome a difficult road while the coward dies («The Glooscap» [32]). «A bold man gets out of his difficulties, a coward loses his life», says the tale "Buh Lion and Buh Goat» [13, p. 490]. «You got to begin charity next door. But if you want to reform, it's got to begin at home», declares «Reform Meeting» [13, p. 492-493]. Generosity, courage, light-heartedness, chivalry, loyalty, clear mind, as in «Billy the Kid» [24], kindness, diligence, obedience, strength, and bringing good to others, as in «The Talking Eggs» [11] are the components of pedagogic justice model.

\section{Discussion}

Taking into account the justice models analyzed above, I can assume that the common American justice model corresponds to the formula $\mathbf{J}=\mathbf{R} / \mathbf{E}$ (pgcmdtev) where $\mathbf{J}$ is justice, $\mathbf{R}$ stands for resources, $\mathbf{E}$ means efficiency. In American folk tale efficiency demands $\mathbf{p}$ for peaceful coexistence, $\mathbf{g}$ for family life, care for children, the women, and the weak, $\mathbf{c}$ for common good, $\mathbf{m}$ for social mobility opportunities, $\mathbf{d}$ for development, $\mathbf{t}$ for truth, e for equal rights, and $\mathbf{v}$ for virtue. Virtue includes excessive vitality, wit and intelligence, knowledge of and adherence to accepted norms of behavior, kindness, and skillful industrious work. The formula of American justice turns out to be different from the formulas of Mordovian and Spanish justice that I derived earlier. This information can be useful in interpreting the models of justice of different ethnic groups.

A detailed analysis of the models of justice allowed me to identify the functions that justice performs in the society.

The epistemological function of justice models in folklore is revealing congruity and incongruity to the truth.

The ontological function of justice is social control, restoration of equality, socialization, the forming of norms, regulation, strengthening public solidarity, integration, and differentiation.

The logical function of justice is revealing the ethnos's logic type, exposing errors of logic and thinking, including violations of common sense, with the subfunction of detecting stupidity.

The linguistic function of justice is to identify truth and falsehood, norm and deviation, values and vices through linguistic means, specifically nominative and indicative deixis, forming stereotypical evaluations and assessments.

The historical function of justice is eliminating inadequate assessments of the past. 


\section{Conclusion}

Summarizing the models of justice in the American folk tale I can draw the following conclusions.

The set of justice models I have obtained allows us to form a dimensional, complete, and systematic image of ethnocultural justice and a better understanding of American culture.

The study shows that the models of justice in the folklore of Native Americans, African Americans, European pioneers, later migrants, and modern Americans have a wide field of universal components but are not identical; are similar to the models of justice of other cultures, but have differences from them. These differences must be taken into account to carry out the dialogue of cultures with respect to local justice. The study results reveal the unique features of the Native Americans, African Americans, European pioneers, later migrants', and modern models of justice.

Care for women and children ensures the continuation of society's life and functioning. Care for the sick ensures the continuation of Homo Sapiens humanity. Following the parents' rules and advice is regarded both as ensuring safety and keeping the tradition. A woman choosing a decent man for a husband, raising healthy offspring in a family in the extended reproduction model is normal. Violation of natural life cycles, adultery, incest, desertion, or mistreating children is regarded as unjust and abnormal.
The unity of mankind and the society, mankind and all living things, and nature, is just and desired as the only way to save humans on earth and the earth for humans. Therefore, war is disastrous, unjust, and destructive.

Social order, equal political rights, and worthy leaders remain judicial components through social changes, including following a tradition and constructing a tradition.

The development of skills, equal educational rights regardless of the parents' income, free choice of a profession, diligent attitude to work, creativity, and excessive vitality contribute to the human and social development, common good, and the improvement of people's lives. The rewards of virtue and punishments of vice are considered just. Depravity, drunkenness, meanness, and laziness are punished by life itself.

Falsehood contradicts justice; justice is a form of truth.

The scientific significance of the research is the identification of the contents of various models of justice and judicial functions in a multi-ethnic American society. These results can and should be applied in the dialogue of cultures. This is the practical significance of this study. In further research, we ought to continue investigating the contents of models of justice of different ethnic and social groups aiming to determine optimal interethnic models of interaction based on justice.

\section{References}

1. Afanasyev, A. N. (1957) Narodnyie Russkie skazki A. N. Afanasyeva [Russian Folk Tales by A. N. Afanasyev in Three Volumes]. Vol. 1. Moscow: Goslitizdat, 515 p. (In Russ.).

2. Gagaev, A. A. (2017) Spravedlivost'v sporte i estestvennom sportivnom prave [Justice in sport and natural sport right]. Bereginia.777. Sova, pp. 149-170. (In Russ.).

3. Gagaev, A. A., Gagaev, P. A. (2019) [Philosophy of mythology and tales about Paelsmurt: a comparative approach]. Mifv vistorii, politike i kul'ture; sbornik materialov III mezhdunarodnoj mezhdistsiplinarnoj konferenstii [Myth in history, politics, and culture; a collection of issues of III International interdisciplinary conference]. Sevastopol: branch of Lomonosov MSU, pp. 123-126. Available at: https://sev.msu.ru/wp-content/uploads/2019/12/ Sbornik-_Mif-2019.pdf (accessed: 11.05.2021). (In Russ.).

4. Gagaev, A. A., Gagaev, P. A. (2017) [Theory of natural and historical justice]. Kazanskij vestnik molodykh uchyonykh [Kazan bulletin of young scientists]. Vol. 1, № 3 (3), pp. 62-65. (In Russ.).

5. Kanarsh, G. Iu. (2011) Sotsial'naia spravedlivost': filosofskie kontseptsii i rossiüskaia situatsiia [Social justice: philosophical concepts and Russian situation]. Moscow: Publishing house of Moscow State University, 236 p. (In Russ.).

6. Kanarsh, G. Iu. (2018) [Justice]. Filosofskaia antropologiia [Philosophical anthropology]. Vol. 4, № 1, pp. 244-262. (In Russ.).

7. Osmushina, A. A. (2021) Ispanskaya narodnaya skazka: sotsialno-filosofskie osnovania, model spravedlivosti [Spanish folk tale: social-philosophical foundations, the model of justice]. Modern Science, Vol. 2, № 2, pp. 269-299. Available at: https://www.elibrary.ru/download/elibrary_44789439_85275247.pdf (accessed: 11.05.2021). (In Russ.).

8. Osmushina, A. A. (2020) [The model of justice in Mordovian ethnic tale]. Finni-Ugorskij mir [Finno-Ugric World], vol. 12, № 2, pp. 212-219. DOI: 10.15507/2076-2577.012.2020.02.212-219 (In Russ., abstract in Eng.).

9. Sychev, A. A. (2016) Etika ekologicheskoy otvetstvennosti [Ethics of the ecological responsibility]. Moscow: Alfa-M, 520 p. (In Russ.)

10. Torosian, O. A. (2012) [Idea of justice in the context of the theory of «natural rights of the human»]. Izvestiia vysshikh uchebnykh zavedenii. Seriia: Gumanitarnye nauki [Bulletin of high schools. Series: Humanities]. Vol. 3. № 3, pp. 233-236. (In Russ.). 
11. Botkin, A. B. (1944) A Treasury of American Folklore: Stories, Ballads, and Traditions of the People. Crown Publishers. Available at: https://archive.org/details/in.ernet.dli.2015.29419 (accessed: 11.05.2021). (In Eng.).

12. Coffin, T. P. (ed.) (1961) Indian tales of North America: an anthology for the adult reader. Philadelphia: American Folklore Society. Available at: https://archive.org/details/indiantalesofnor13coff/page/n1/mode/2up (accessed: 11.05.2021). (In Eng.).

13. Courlander, H. (ed.) (1966) A treasury of Afro-American folklore: the oral literature, traditions, recollections, legends, tales, songs, religious beliefs, customs, sayings, and humor of peoples of African descent in the Americas. New York: Smithmark Publishers. Available at: https://archive.org/details/treasuryofafroam00cour/ page/296/mode/1up (accessed: 11.05.2021). (In Eng.).

14. Dallmann, A., Lenz, G. H. (2007) Justice, Governance, Cosmopolitanism, and the Politics of Difference. Berlin, Humboldt-Universität, 152 p. (In Eng.).

15. Dorson, R. M. (ed.) (1959) American folklore. Chicago and London: The university of Chicago press. Available at: https://archive.org/details/americanfolklore00dors/page/n7/mode/1up (accessed: 11.05.2021). (In Eng.).

16. Dorson, R. M. (ed.) (1983) Handbook of American folklore. Bloomington: Indiana university press. Available at: https://archive.org/details/handbookofameric0000unse_v2h6/page/n7/mode/1up (accessed: 11.05.2021). (In Eng.).

17. Gagaev, A. A., Gagaev, P. A., Osmushina, A. A. (2020) The theory of the natural justice. Modern science, 1-1, pp. 350-358. Available at: https://www.elibrary.ru/item.asp?id=41870359 (accessed: 10.04. 2021). (In Eng.).

18. Green, T. A. (ed.) (2006) The Greenwood library of American folktales. Vol. 2. Westport, Connecticut, London: Greenwood press. Available at: https://archive.org/details/greenwoodlibrary0002unse/page/66/ mode/1up?q=education (accessed: 11.05.2021). (In Eng.).

19. Grimm, J., Grimm, W. (1815) Kinder- und Hausmaerchen. Berlin: Realschulbuchhandlung. Available at: https://archive.org/details/GrimmKinderUndHausmaerchen2-1815/page/n22/mode/1up (accessed: 21.05.2021). (In Germ.).

20. Harding, N. (2006) Urban legends. Chichester: Pocket Essentials Collection. Available at: https://archive. org/details/urbanlegends0000hard/page/18/mode/2up (accessed: 21.05.2021). (In Eng.).

21. Honneth, A. (1995) The struggle for Recognition: The Moral Grammar of Social Conflicts. Trans. Anderson, Joel. Cambridge, PolityPress, 215 p.

22. Jack, A. (2013) Phantom hitchhikers and other urban legends: the strange stories behind tall tales. New York: Perigree. Available at: https://archive.org/details/phantomhitchhike0000jack/page/n3/mode/2up (accessed: 21.05.2021). (In Eng.).

23. Laval, R. A. (1923) Cuentos polpulares en Chile (recogidos de la tradición oral). Santiago de Chile: Imprenta Cervantes. Available at: https://www.gutenberg.org/files/63424/63424-h/63424-h.htm (accessed: 20.05.2021). (In Span.).

24. Leeming, D. A., Page, J. (1999) Myths, legends and folktales of America: an anthology. New York: Oxford University Press. Available at: https://archive.org/stream/mythslegendsfolk00davi (accessed: 15.05.2021). (In Eng.).

25. Lincoln, A. (2004) First Inaugaral Address In American Constitutional Law: Essays, Cases, and Comparative Notes. Eds. Kommers, Donald P./Finn, John E./Jacobsohn, Gary J. Rowman\&Littlefield, pp. 727-730. (In Eng.).

26. McCarthy, W. B. (ed.) (2007) Cinderella in America: a book of folk and fairy tales. University Press of Mississippi/Jackson. Available at: https://archive.org/details/WilliamBernardMccarthyCinderellaInAmerica/page/ n7/ (accessed: 17.05.2021). (In Eng.).

27. Propp, V. (1968) Morphology of the folk tale. Trans. Scott, Laurence. Austin: University of the Texas Press. Available at: https://archive.org/details/morphologyoffolk00prop/page/158/mode/2up (accessed: 20.05.2021). (In Eng.).

28. San Souci, R. D. (1998) A terrifying taste of short \& shivery: thirty creepy tales. New York: Delacorte Press. Available at: https://archive.org/details/isbn_9780385326353/page/2/mode/2up (accessed: 17.05.2021). (In Eng.).

29. San Souci, R. D. (2003) Even more short \& shivery: thirty spine-tingling tales. New York: Dell Yearling/ Random House. Available at: https://archive.org/details/evenmoreshortshi00robe/page/n5/mode/1up?q=still+mor e+short+and+shivery (accessed: 15.05.2021). (In Eng.).

30. San Souci, R. D. (2002) More short \& shivery: thirty terrifying tales. New York: Dell Yearling Books. Available at: https://archive.org/details/moreshortshivery00robe/page/n1/mode/2up?q=Don\%27t+Look+Back\%3 A+Thirteen+Terrifying+Tales+of+Urban+Folklore (accessed: 15.05.2021). (In Eng.). 
31. Segaloff, N. (2001) The Everything tall tales, legends \& outrageous lies book. Holbrook, Mass.: Adams Media Corp. Available at: https://archive.org/details/everythingtallta0000sega/page/n8/mode/1up?q=stud (accessed: 15.05.2021). (In Eng.).

32. Thompson, S. (ed.) (1955) Folk tales of the North American Indians. North JG Press. Available at: https:// archive.org/details/folktalesofnorth0000unse/page/n12/mode/1up (accessed: 20.05.2021). (In Eng.).

33. Toelken, B. (1979) The dynamics of folklore. Houghton muffin company. Available at: https://archive.org/ details/dynamicsoffolklo0000toel/page/225/mode/1up (accessed: 17.05.2021). (In Eng.).

34. Young, D. R., Young, D. J. (1994) The Scary story reader : forty-one of the scariest stories for sleepovers, campfires, car \& bus trips-even for dates! Little Rock, Ark.: August House. Available at: https://archive.org/details/ scarystoryreader00rich/page/174/mode/1up (accessed: 21.05.2021). (In Eng.).

35. Watts, L. S. (2007) Encyclopedia of American folklore. Boston: Checkmark books. Available at: https:// archive.org/details/encyclopediaofam00lind/page/n8/mode/1up (accessed: 21.05.2021). (In Eng.).

Information about the author:

Anastasia Andreevna Osmushina, Candidate of Philosophy, Associate Professor of the Department of English language for professional communication, Federal State Budgetary Educational Institution of Higher Education «National Research Ogarev Mordovia State University», Saransk, Russia

ORCID ID: 0000-0003-2982-2772

e-mail: 98761985@mail.ru

The paper was submitted: 27.05.2021.

Accepted for publication: 22.09.2021.

The author has read and approved the final manuscript.

\section{Информация об авторе:}

Анастасия Андреевна Осьмушина, кандидат философских наук, доцент кафедры английского языка для профессиональной коммуникации, ФГБОУ ВО «Национальный Исследовательский Мордовский государственный университет им. Н. П. Огарева», Саранск, Россия

ORCID ID: 0000-0003-2982-2772

e-mail: 98761985@mail.ru

Статья поступила в редакцию: 27.05.2021; принята в печать: 22.09.2021.

Автор прочитал и одобрил окончательный вариант рукописи. 